\title{
From Concealment to Différance. Upon a Hidden Foundation of Being from the View-Point of Jan Patočka and Jacques Derrida
}

\author{
Anna Maria Skibska, PhD \\ University of Adam Mickiewicz in Poznań \\ nnskibska50@gmail.com
}

\section{Doi:10.5901/mjss.2013.v4n9p579}

\section{Abstract}

The paper attempts to cast some light on a moment of transition from the discourse of phenomenology, regarded as the very source of Patockka's and Derrida's works, to its peculiar antithesis or negation that consists in the act of dislodging from belief in the omnipotent human ratio. In order to unveil an extra-ordinary similitude between the comportments of both the thinkers, the crucial terms of concealment, derived from the essays of the Czech philosopher, and of Derrida's famous differrance are to be juxtaposed, and subsequently explored and eventually commented in the paper. In accordance with such a gesture, the paper tends to indicate a hidden foundation of being that reveals itself as a phenomenon impossible to define, or capture in some other, non-lingual modes, since its representation, however necessary, always turns out to be inaccurate. Instead of the socalled final explication, the paper, making a visible usage of Heidegger's manner of writing "under erasure", will focus on a secret existence of concealment and of difference due to examine their manifestations, henceforth comprehended as their necessary work or action. Thus both the thinkers are to be considered as the precursors of the post-phenomenology, or "phenomenology above lights", to quote the quasi-transcendental Lévinas, who devote themselves to the elliptical realm of the hidden.

Keywords: concealment, différance, ellipsis, question, post-phenomenology

The relation of art to life is of the first importance especially in a skeptical age since, in the absence of belief in God, the mind turns to its own creations and examines them, not alone from the esthetic point of view, but for what they reveal, for what they validate and invalidate, for the support that they give. Wallace Stevens (1997, p. 916)

As is well known to the readers of Derrida, many of his texts are framed (and equipped) with various inter-texts which are conventionally modeled on the form of motto namely, on the very same structure I have decided to initiate into my own essay. Such a gesture usually maintains a seriousness of introduction, instructing how to proceed with a whole signature that is given to us, however, it also preserves something I wish to call a negative inspiration, since it might be used against certain properties of the discourse that is, its coherence, order, or logic. In Archive fever (1995), Derrida himself highlights an intriguing character of epigraph by making an assertion that "To cite before beginning is to give the tone through the resonance of a few words, the meaning or form of which ought to set the stage. In other words, the exergue consists in capitalizing on an ellipsis" (p. 7). Instead of the motto, the thinker refers to the phenomena of epigraph and of exergue, since they are to confirm an unique value of inscription - its singularity, concealed under some date and some name of either person (epigraph) or place (exergue) ${ }^{1}$. Thus we are entering into the realm of absence, expressed by a figure of ellipsis, in the name of which one is expected to keep asking, because "The starting point and the heart of all philosophy is not any doctrinal answer but rather the posing of the philosophical question itself" (Kohák, 1989, pp. 4-5). To capitalize on an ellipsis therefore means to protect a singular event of (textual) being against the traditional manner of apodictic statement, in other words, against the canonical interpretation that tends solely to invalidate all the others.

The motto that inaugurates my own narration was chosen not only because of its content, affirming a thought that supports a reflective subjectivity by being in a constant movement, but also with regard to the anxiety of influence, elaborated by Harold Bloom while reading the strong poets. Among of them one may easily come across the author of the above quoted words. Bloom's concept, streaked with Emerson,Freud and Nietzsche, allows to illuminate a struggle that concerns each scene of writing, for in each of them an exchange occurs, an exchange that, idealistically speaking,

${ }^{1}$ As for the meaning of exergue, it refers to a space on the reverse of a coin or medal below the central design, often containing the date, place of engraving, etc. With regard to the first term, of epigraph, Derrida's choice seems to be obvious, for the term denotes, besides a quotation or motto placed at the beginning of the text, an inscription on a monument or coin (Baldick, 2008, p. 113). 
leads to the birth of a new idiom. Despite of being rather a result of Emersonian re-centering than a de-centering, invented by Nietzsche and handed over to Derrida or de Man, the ideas of misreading and misprision, conjoined with the anxiety of influence, assume an essential strategy of counter-writing that regards the precursors' works². To become a strong writer therefore means to situate in an opposition to the other languages which are to shape one's identity. For Derrida and Patočka, as well as for Heidegger and Lévinas, the first other language is the language of Husserl's phenomenology which unveils itself not as "a matter of inner conduct" (Patočka, 2002, p. 1), but as an extremely coherent, since based on the logical principles, system of a pure inspection of the way the world looks like. The system subsequently results in a description and an analysis, focused on a "production" of a never-ending series of phenomena that are to inhabit one's consciousness. In order to illuminate the crucial reason, for which Husserl's language had to be overcome by his pupils, one ought to recognize its limitations that eventually cause the philosopher's shift to the terrain of transcendental idealism, thus depicted by the Czech thinker:

In the course of the development of phenomenology, transcendental consciousness was broadened into "transcendental intersubjectivity" so that the relation between consciousness and the world of things was inverted: in place of little islands of consciousness in a sea of a first naturally, then natural-scientifically conceived objectivity, we came to think of an ocean of intersubjectivity surrounding the continent of the objective world which served to mediate between individual transcendental "streams" of experience (Patočka, 1996, pp. 4-5).

The author of Heretical Essays in the Philosophy of History distances from the precursor's comportment also because of the status of sense, since it is constantly regarded, in Husserl's system, by idealistic means according to which sense itself is to be previously given namely, prior to human thought, already fastened in the objective world as the universal, source, and unchangeable data. Thus the work of creation that is, the real name of the philosophical discourse, must be substituted for an anachronistic conviction as for the cognitive abilities of the omnipotent human ratio, always streaked with desire to know more and better. To know more and better therefore comes always down to power that is to seize over the world, and to turn writing into the book, as Derrida would say, since he announces that "The horizon of absolute knowledge is the effacement of writing in the logos, the retrieval of the trace in parousia, the reappropriation of difference, the accomplishement of (...) the metaphysics of the proper" (italics - J. D., 1997, p. 26). When Patočka speaks of the inner conduct he is already far away from this philosophy of possession, since he is aware of their dangerous consequences; what he has to propose is a meditation without decision ("a situation is a situation precisely because it has not yet been decided", 2002, p. 4) that assumes a non-conclusive manner of thinking, since "the only valid philosophical answer to the Socratic question is a 'negative' one which does not seek to eliminate the question with a definite answer but which continues to grapple with it. Not the fixed product but the ongoing process of philosophy is the valid response" (Kohák, 1989, p. 8). In the just quoted words, there are expressed two crucial issues which allow to take under consideration that a situation of the Czech thinker locates itself in the very neighborhood of a situation of Derrida, presented in his deconstructive practices of reading. For, as Barbara Johnson points out, the French "philosopher" introduces himself as "a reader who constantly reflects on and transforms the very nature of the act of reading" ( $p . X$, in: Derrida, 2004). The both thinkers therefore operate against the metaphysical thought of closure, however, not to dissolve a problem (since it assumes a necessity of decision, or answer), but to unveil its real "problemacity" that is to occur under one condition namely, their creative involvement into it. In order to adjust oneself to a problem, always conjoined with reiteration as already articulated by the precursors or the inter-texts, one has to comprehend it in terms of work that necessarily must not to be completed or done, especially if it is to "help us in the distress in which we are" (Patočka, 2002, p. 1) , or to "produce an effect of indefinite fluctuations between (...)

\footnotetext{
${ }^{2}$ According to Bloom (2003), the procedure of re-centering consists in „a mode that is intra-textual, but that stubbornly remains logocentric, and that still follows Emerson in valorizing eloquence, the inspired voice, over the scene of writing. Emerson, who said he unsettled all questions, first put literature into question for us, and now survives to question our questioners" (p. 176). Besides Stevens, the other American poets who participate in the agon, initiated by the author The Conduct of Life, are Whitman and Dickinson.

3 The reasons of our modern distress are penetratingly described by Patočka himself (2002), and with accordance to them "We are the victims of contradictory prophets, some proclaim the unleashing of instincts, others absolute discipline and obedience; both seem to be two sides of the same thing. Thus a deep helplessness a distress. There does not exist any joyful work of art; nothing exists except an enormous tangle of human activities. Every human initiative or deed is socialized, controlled, and integrated into current affairs and carried off alone into the unknown. This is a sentiment of alienation. What grows from it is surprisingly something like a will to power, but power that has no subject. It is not that someone should want this power; it is just accumulated and does what it wants with us. Here is an awareness of a horrible trend toward abyss. That we cannot get off the ship carrying us in a certain sense to the sad recognition of this worldly fall, this decline of nature and man, as if it were an irreversible and inescapable fall. In this situation something like metaphysics (only to say the word) is laughable! For us, recalling something like metaphysics or Mozart's art, or the art of The Chartres
} 
possibilities" (Derrida, 2004, p. 234). How to combine the above quoted insights into a common situation, since they speak in the name of some different, as it seems, interests? In order to attempt to face such a question, one ought to turn to The Gift of Death (Derrida, 1995), for in its first chapter, entitled "Secrets of European Responsibility", the French thinker elaborates on Patočka's Heretical Essays (1996) ${ }^{4}$, and, as befits Derrida, makes it in the cross-shaped poetics of chiasmus that initiates into an intriguing exchange between the signature (by Patočka) and the counter-signature (by Derrida). Due to this exchange, the term of responsibility should be considered in the first place (and it really is by being the title word, for "titulus", as Derrida writes elsewhere, "includes a sense of gathering") ${ }^{5}$ since it entails a secrecy that is understood as a "demonic mystery" that itself turns out to be a hidden foundation of religion. Derrida (1995) therefore repeats, after the Czech thinker, that "religion comes into being the moment that the experience of responsibility extracts itself from the form of secrecy" (p. 3). To engage himself into the chiastic inter-play, the author of Dissemination recalls the three stages of the history of responsibility, previously distinguished by Patočka namely: 1) prehistory, 2) philosophy as the invention of the Greek polis, and, 3) Christian religion. The first stage, of prehistory, is perceived in the horizon of non-concealment, since it simply consists of the two times: of the daily existence and of the demonic mystery that refers to the night, the sphere of ancient orgiastic cults. In the second stage, described through the figure of Socrates, the figure that means the very beginning of philosophy, the time of night, of demonic mystery, becomes subordinated to the Greek polis that develops itself in the bright light of the day, that is in other words, in the light of human mind. Nevertheless, as Derrida reveals, such a "subordination never means elimination" (p. 9), and then he refers to an event of the first tremor that results in Platonism. Thus the history of secrecy, derived from the turn towards exteriority (expressed by a notion of the other) and accessibility (with regard to this turn, Patočka speaks of conversion while Derrida chooses another word, of revolution), might be conceived as a substitution wherein the repressed content of demonic mystery is also retained in the realm of concealment. Due to this substitution, one is allowed to talk about a sign, assumed together with its core activity of deferring presence according to which instead of an athematic mystery there comes the accessible word of responsibility namely, "the relation to self as being before the other" (Derrida, 1995, p. 3). Moreover, the experience of responsibility is tied to the appearance of a subjectivity freed (only apparently) from the essential secrecy that is manifested by a rupture between absence-of-the-self and presence-of-the-other. The other who enables responsibility is created out of a primal catastrophe of the self that I am forced to locate in a paradox place, a place prior to any discourse, for it has nothing in common with knowledge and history. The singular self participates only in mystery of which essence must remain unknown if it is to maintain its value of secrecy. To this must be added something else. The self before rupture knows nothing and for that reason it doesn't know why dies, in other words, it does experience its own mortality without distress namely, without reflection. An issue of death, tied to the other, becomes a problem which is born out of responsibility that illuminates freedom of subjectivity, freedom of Socrates who accepts his own death voluntarily. Responsibility for death, either our own or death of the other, explains itself in terms of taking control of death that is triumphantly overcome by creating an adequate theme which subsequently replaces death itself. With regard to "this event of looking death in the face", Patočka adds, "the triumph over death" (that is, "the triumph of life") takes place according to which "the soul is absolutely free, it chooses its own destiny" (1996, p. 115). Derrida's interjection, however, reminds us that this "triumph retains traces of a struggle" (1995, p. 16), for death is still there, hidden inside of us, in every one with no exception.

As for the second tremor, referring to the third stage, of Christianity, it presents itself as another substitution that regards a necessary modification in the field of death, since it distinguishes a figure of gift. A figure that is to cover a figure of death. I will make use of Derrida because he elaborates on this plot in a manner that corresponds to the further parts of my essay:

This becoming-responsible, that is, this becoming-historical of human kind, seems to be intimately tied to the properly Christian event of another secret, or more precisely, the mysterium tremendum: the terrifying mystery, the dread, fear and trembling of the Christian in the experience of the sacrificial gift. This trembling seizes one at the moment of becoming a person, and the person can become what it is only in being paralyzed [transic], in its very singularity, by the gaze of God. Then it sees itself by the gaze of another, a supreme, absolute and inaccessible being who holds us in his hand not by exterior but by interior force (Patočka, 1996, p. 116, in: Derrida, 1995, p. 6; italics - the author).

(...)

cathedral, makes it seem absolutely unreal. We no longer are able to find and experience any joy in it, or to raise ourselves up to something like it. That is the entire sentiment of our time" ( p. 6; italics - the author).

${ }^{4}$ To be more precise, Derrida immediately refers to the particular essay of Patočka that is, "Is Technological Civilization a Civilization in Decline, and If So Why?".

5 The quotation derives from the beautiful essay of Derrida, entitled Shibboleth for Paul Celan (1994, p. 34). 
The secret of the mysterium tremendum takes over a heterogeneus secrecy and at the same time breaks with it. This rupture takes the form of either subordination by incorporation (one secret subjects or silences the other) or repression. The mysterium tremendum gets carried away [s'emporte], in the double sense of the term: it rises against another mystery but it rises on the back [sur le fond] of a past mystery. In the end [au fond] it represses, repressing what remains its foundation [suis fond] (Derrida, 1995, p. 7; italics - the author).

Henceforth, incorporated or repressed, the foundation of the history of secrecy has to inhabit interiority and, by this displacement, it constitutes another figure, of abyss, that envelops a non-order of the inaccessible. Derrida also speaks of the economy that ought to be considered, firstly, as the economy of sacrifice, especially that the essential Christian dogma, of the Holy Trinity, is based on it. To meet requirements of that economy, there must appear a problem of taking possession of something that can be sacrificed. For more than obvious reason, it is a matter of life, since it remains at disposal of everything that is alive. To be alive means to owe life, and this possession conditions each sacrifice. The economy of sacrifice turns out to be streaked with "the economy of sublation" or with a movement of repression, coined by Freud while investing his psychoanalytical project with proper significance6. In The Gift of Death, as well as in the other texts of Derrida, his counter-signature consists of many signatures which refer not only to Patočka and Freud, but also to Heidegger, Hegel and Kierkegaard, or to religions of the Book (Christianity, Judaism, Islam). The visual trace of Hegel's language appears in the term of sublation (Aufhebung/Aufheben) of which double sense the German philosopher makes use while elaborating on the interaction of a thesis and antithesis. The term therefore means to lift up, to abolish, to sublate, to preserve, to transcend, to cancel, to keep, and its antithetical values of preservation and modification at the same time must remain valid if the process of synthesis is to succeed. Thus each synthesis, especially the historical one, since it regards the spiral inter-play of absence and presence, must unavoidably submit to that permanent sequence of incorporation and repression according to which "Responsibility triumphs over the orgiastic and incorporates it within itself as a subordinated moment" (Patočka, 1996, p. 114). This statement is supplemented by Derrida (1995) in the following words: "Platonic mystery (...) incorporates orgiastic mystery and Christian mystery represses Platonic mystery" (p. 9; italics - the author). Yet the both thinkers cannot restrain themselves from investigating of this inversion, since they constantly turn back to the beginning of their "history" ("historicity"):

Then there is the structure of secrecy that keeps that mystery hidden, incorporated, concealed but alive, in the structure of free responsibility that claims to go beyond it and that in fact only succeeds by subordinating mystery and keeping it subjugated. The secret of responsibility would consist of keeping secret, or "incorporated", the secret of the demonic and thus of preserving within itself a nucleus of irresponsibility or absolute unconsciousness, something Patočka will later call "orgiastic irresponsibility" (Derrida, 1995, p. 20; bold - A. S.)

Due to those significant re-returns, affirming an essential property of language that is, its reiteration, and inscribing themselves into a poetics of the ring (reprise, composition annulaire) of which striking power reveals Shibboleth for Paul Celan (Derrida, 1994), one needs to consider their reasons that seem, at least in my very opinion, identical for the both thinkers. They come after all from the same parts of the discourse, aren't they? Firstly, it is a matter of hope that promises a change according to which one, to return, always chooses a different path. Secondly, the gesture of return proves a peculiar attraction that is carried within itself by the sphere of concealed, its inspiring absence that imposes a necessity on posing questions which enable the inner conduct to go on. Thirdly (it's worth noticing that provided with the third reason, we are to exceed the dual structure of the sign), what provokes the most is not necessarily the concealed itself - to remain as such, to retain its mystery, it cannot be unveiled - but a commitment, resulted from responsibility, that keeps calling for movement in the direction of the concealed. It entails that the "nucleus of irresponsibility", however inaccessible, ought to be estimated as the constitutional element of responsibility?. Thus there is always unnamed in the field of named ("a new space of reading", according to David Woods, 1992, p. 3) that persistently suggests an effect of synecdoche, ellipsis, or aposiopesis, since all those figures promise what is impossible namely, a paradox idea of infinite totality that would possibly resemble a synthesis of knowledge and non-knowledge. Besides, this what we call the vivid inspiration comes only from the latter. Non-knowledge might be even compared to a phenomenon of stigma about which

\footnotetext{
${ }^{6}$ In "Freud and the scene of writing", Derrida (2010) juxtaposes the psychoanalytical repression with its logocentric version, and he claims that "logocentric repression is not comprehensible on the basis on Freudian concept of repression; on the contrary, logocentric repression permits an understanding of how an original and individual repression became possible within the horizon of a culture and a historical structure of belonging" (p. 248).

${ }^{7}$ According to Robert Bernasconi (1997), "What makes responsibility unequal to itself is the fact that 'one is never responsible enough'. This arises not just because one is finite, but also because responsibility exhibits a contradictory movement. One not only responses in one's irreplaceable singularity for what one does, says, and gives, but also inasmuch as one is good, forgets and effaces of one's giving" (pp. 263-264).
} 
Hélène Cixious (2008) says that it "wounds and spurs, stimulates" (p. xiii; italics - the author). Henceforth, the concealed can be regarded as a spur (stimulus) for writing, and, as such, it is to lead to a text that breaks free of the discursive shackles. Nevertheless, as Norris points out:

The autonomy of the text is actively invaded by a new and insubordinate style of commentary which puts in question all the traditional attributes of literary meaning. But at the same time this questioning raises literature to a point of rhetorical complexity and interest where its moments of "blindness" are often more acutely revealing than anything in the discourse of philosophy (2002, p. 24).

In the course of a simultaneous or parallel reading of Patočka and Derrida, a certain thought arises with accordance to which I will allow myself a short digression. In order to cast some new light on the title problems, I am going to venture a "foreign" context, so to speak. In Illuminations (1999), Walter Benjamin attempts to formulate his own attitude towards Kafka's works, and, to achieve it, he establishes an interesting field that spreads between four figures: of Potemkin, of a childhood photograph, of the little hunchback, and of Sancho Panza. Let me focus on the first figure because it will lead us to the assistants ${ }^{8}$, the strange creatures accompanying $\mathrm{K}$. in The Castle. With regard to these assistants, Benjamin (1999) makes use of the gandharvas, derived from Indian mythology, who introduce themselves as "celestial creatures, beings in an unfinished state. (...) neither members of, nor strangers to, any of the other groups of (Kafka's - A. S.) figures, but, rather messengers from one to other" (p. 113) ${ }^{9}$. To call them messengers unavoidably means to perceive them through their pure action, that concerns neither waiting for, nor doing something particularly, called thus learning. Since the assistants are unfinished, they may remain in a situation of Patočka's openness (1996, pp. 5-7) that constantly exposes itself to the slight adjustments. Speaking of such an openness, Patočka developes Heidegger's notion of "being open to what there is (to which being belongs)" (p. 5) that ultimately drifts towards a reinterpretation regarding a core device of Husserl's language namely, a phenomenon itself:

(...) the structure of openness entails a double conception of the phenomenon. The openness of human being-inthe-world, first of all, lets what-is appear, manifest itself, become a phenomenon.

Secondly, though, if what-is is to show itself forth as such, that is, in its being, it must be possible for being, too, to present itself and become a phenomenon. Being, however, is originally and for the most part "there" in such a way that it retreats into obscurity (bold $-\mathrm{A}$. S.) before the existent whose manifestation it made possible, that is, so to speak, Being conceals itself in what there is (bold - A. S.). Concealment in its various forms - is an essential aspect of a phenomenon. Every phenomenon must be understood as a lighting, a coming from concealment and never otherwise. Concealment penetrates the phenomenon and more: it is what first releases from itself the being which manifests itself $(1996$, p. 7).

Due to such a redefinition of phenomenon, whether it regards the being or any other object that is to be taken under consideration, it also retains its mystery namely, this meaningless something that enables the constitution of the so-called proper meaning. The hidden or absent foundation of phenomenon, of which content is necessary yet always inaccurate, since it solely reveals its intelligible part, allows to assume Patočka's individual gravitation towards this what I propose to name post-phenomenology. This post-phenomenology, continued by Derrida, opens itself up to history that is streaked with heresy, commented in the following passage:

In Patočka's view (...), "heretic" is tied to heresy, hairesis as choice, election, preference, inclination, as well as divergence within a doctrine; it surpasses the objectivity of knowledge. (...) it is a matter of "creating something new out of catastrophe", a heretical, practical decision that goes beyond any theoretical or thematic determination; it is tied to divergence, to polemos and strife (llea/hermeneia.ro)

Supported by the above quoted fragment, I would like to juxtapose Patočka's divergence (within the phenomenological discourse) with Derrida's différance, since the both terms underscore the five properties that are to be practiced in the structures of language namely, impossibility of origins (the fundamental secrecy), lack of identification (the inter-play between concealment and manifestation), splitting work of temporality (absence vs. presence), producing of another differences (invention), and strife (that is to be inscribed in the ethical horizon of post-phenomenology or

\footnotetext{
${ }^{8}$ Benjamin (1999, p. 113) compares Kafka's assistants to the characters appearing in the short novel of Robert Walser, Der Gehülfe (The assistant) that belonged to the favorite books of the author of The Trial. Moreover, Benjamin conjoins their mysterious existence with a perspective of the future, by saying: "It is for them and their kind, the unfinished and the bunglers, that there is hope" (p. 113). The messengers, expected or unexpected, never have expectations on their own, and that is, perhaps, why they are the only ones who truly deserve hope. To complicate their vague status, one might also consider the extremely different view-point of Bloom (1991) who conceives them as a parallel to Job's abominable friends, called after Blake "pious timeservers" (p. 19).

${ }^{9}$ Gaskell (1981) introduces gandharvas (or sirens) in the following words: „Symbols of Devas of the buddhic plane, which assist in establishing harmony in the soul through the aesthetic emotions" (pp. 299-300).
} 
deconstruction). Divergence, alike Derrida's aethesis (1987, p. 261) ${ }^{10}$ of which thought originates from différance, refers to a procedure that has been already expressed as the inner conduct (that is to render a matter of philosophy). In the semantic field of the very word, there are inscribed significantly different meanings, especially when we are to consider its verbal form. Due to this, 'to conduct' might be explicated as to lead, to manage, or to defense, while the noun 'conduct' refers to behavior (usually towards somebody) or handling (of campaign, business). If one combines this constellation of meanings with the epithet 'inner' that is obligatory element of Patočka's expression, its divergence becomes possible to grasp. It indicates therefore a secret passage wherein the movement from concealment to manifestation, assumed in the dual phenomenon of the Czech thinker, takes place, however, it also suggests a temporal gap between absence and presence which itself is underscored by a necessary gap between 'inner' and 'conduct'. Thus Patočka and Derrida have managed to reverse phenomenology by investing, each of them in his own way, in this mysterious transition from the realm of 'inner' that is, the hidden foundation of being, to the elliptical order of 'outer' that retains (at least the thinkers claim so)in its visible and/or audible forms a trace of the concealed, either buried or reanimated in the form of a specter. Patočka himself never coined any extravagant term, as Derrida did by inventing différance, in order to give a name to his own condition that turns out to be of double bind, nevertheless, his returning approach to the movement, resulted in divergence, can lead us to the contradictory conclusions. On the one hand, the Czech thinker might be regarded as a traditional philosopher, tied up to the phenomenological discourse to such an extent that he simply cannot abandon it by creating a "new" language. But on the other, no to invent a name for this worrying and exciting movement and leave it as it is - in its athematic envelope - might be also interpreted as an act of the most responsible courage, displayed in the face of paralyzing presence. For that reason, I have recalled Kafka's messengers whose mission can be conceived from the view-point of divergence or difference, since they are an unidentified token of this movement, of this mediation between those two hypothetical natures: of presence and of absence. If I name them, after Kafka, Arthur and Jeremiah, I will have to end with their work, given to them by K.:

'How am I going to tell you apart? The only difference between you is your names (...) you're as like each other as two snakes. (...) I shall call you both Arthur. If I send Arthur off anywhere you must both go, and if I give Arthur a job to do you must both do it. That has the great advantage for me that you both carry the responsibility for all the work I give you. How you divide work up between you I don't care, but you mustn't make excuses by blaming each other you're both one man as far as I'm concerned" (Kafka, 2009, p. 19).

\section{References}

Benjamin, W. (1999, pp. 108-135), Illuminations, trans. by H. Zorn, introduction by H. Arendt, London: Pimlico.

Bernasconi, R. (1997). What goes around comes around: Derrida and Levinas on the economy of the gift and the gift of genealogy. In: A. D. Schrift (ed.), The logic of the gift: towards an ethics of generosity (pp. 256-273), New York, London: Routledge.

Cixous, H. (2010, p. xiii), Stigmata. Escaping texts, trans. by E. Prenowitz, foreword by J. Derrida, Padstow: Routledge.

Derrida, J. (1995, p. 7), Archive fever. A Freudian impression, trans. by E. Prenowitz, London, Chicago: The University of Chicago Press.

Derrida, J. (1986). Différance. Trans. by A. Bass. In: M. C. Taylor (ed.), Deconstruction in context. Literature and philosophy (pp. $396-$ 420), Chicago, London: The University of Chicago Press.

Derrida, J. (1997, pp. 6-26), Of grammatology, trans., with a preface, by G. Ch. Spivak, Baltimore, London: The Johns Hopkins University Press.

Derrida, J. (1987, p. 261), Postcard. From Socrates to Freud and Beyond, trans. by A. Bass, Chicago, London: The University of Chicago Press.

Derrida, J. (1994). Shibboleth for Paul Celan. Trans. by J. Wilner. In: A. Fioretos (ed.), Word traces: readings of Paul Celan (pp. 3-73), Baltimore: The Johns Hopkins University Press.

Derrida, J. (1995, pp. 1-34), The gift of death, trans. by D. Wills, Chicago: The University of Chicago Press.

Derrida, J. (2010, pp. 246-291), Writing and difference, trans., with an introduction and additional notes, by A. Bass, London, New York: Routledge.

Fisher, M. (1990). Does deconstruction make any difference? In: H. J. Silverman, G. E. Aylesworth (eds.), The textual sublime. Deconstruction and its differences (pp. 23-30), New York: State University of New York Press.

\footnotetext{
${ }^{10}$ Derrida (1987) explains this aethesis in his unforgivable manner: "Drifting designates too continuous a movement: a rather too undifferentiated, too homogenous a movement that appears to travel away without saccade from a supposed origin, from a shore, a border, a coast with an indivisible outline. Now the shore is divided in its very outline, and there are effects of anchoring, collapses of the coastline, strategies of approach and overflow, strictures of attachment or of mooring, places of reversion, strangulation, or double bind. These are constitutive of the very process of aethesis, and must be accounted for, if at least there is here something in such an event to be read and to be reckoned with" (p. 261).
} 
Gaskell, G. A. (1981, pp. 299-300), Dictionary of all scriptures and myths, New Jersey: Gramercy Books.

Harvey, I. (1986, p. 226), Derrida and the economy of "différance", Bloomington: Indiana University Press.

Kafka, F. (2009, p. 19), The castle, trans., an introduction, by J. R. Williams, Ware: Wordsworth Editions Limited.

Norris, Ch. (2002, pp. 18-40), Deconstruction: theory and practice, London, New York: Routledge.

Patočka, J. (1996), An introduction to Husserl's phenomenology, trans. by E. Kohák, New York: Open Court Pub.

Patočka, J. (1996), Heretical essays in the philosophy of history, trans. by E. Kohák, J. Dodd (ed.), preface by P. Ricoeur, Chicago and La Salle, Illinois: Open Court Pub.

Patočka, J. (2002), Plato and Europe, trans. by P. Lom, Stanford, California: Stanford University Press.

Patočka, J. (1989), Philosophy and selected writings, trans. by E. Kohák, Chicago: Chicago University Press.

Ray, W. (1984, pp. 141-151), The literary meaning. From phenomenology to deconstruction, London: Basil Blackwell Publisher.

Rorty, R. (1984). Deconstruction and circumvention. Critical Inquiry, vol. 11 (no. 1), pp. 1-23.

Wood, D. (1992). Preface. In: D. Wood (ed.), Derrida: a critical reader (p. 3). Oxford, Cambridge (Mass.): Blackwell Publishers.

Wood, D. (2005, p. 96), The step back: ethics and politics after deconstruction, Albany: State University of New York Press. 